\title{
TRANSLATION AGENCY PROJECT AS A STRATEGY IN TEACHING TRANSLATION THEORY
}

\author{
${ }^{1 *}$ Farida Repelia Waty Kembaren and ${ }^{2}$ Muhizar Muchtar, M.S. \\ ${ }^{1}$ State Islamic University of North Sumatra (UIN SU), Medan, Indonesia \\ ${ }^{2}$ Faculty of Cultural Sciences, University of Sumatera Utara, Medan, Indonesia \\ *Corresponding author: titaancha@gmail.com
}

\begin{abstract}
The practice of teaching translation was often done by discussing translation theories and translating texts in the classroom. However, the problem is students also need to have a real-life experience as professional translators that will be useful for them in the future. This paper presents the findings of a research study conducted in a translation class of English Education Department students in the State Islamic University of North Sumatra. The research is about Translation Agency Project as innovation strategy to teach translation subject. The students were assigned to develop their own translation agency by promoting their agency, handling the clients, and translating the texts. The objective of this research is to identify the challenges faced by the students in running their Translation Agency Project. It also includes how students cope with those challenges. Finally, it describes the benefits of using Translation Agency Project in teaching translation. The method of this research is descriptive qualitative method for translation studies (Toury, 1995) based on theoretical research compared to a survey applied to students of English Education Department who have learned about translation theories. As a result, after analyzing the data, it can be seen that the biggest challenge the students faced in conducting their translation agency is advertising the translation agency (43\%), meeting with clients (36\%), and translating the texts (21\%). Finally, after analyzing the survey, it shows that translation Agency Project is an effective and recommended strategy to teach translation theories in the class.
\end{abstract}

Keywords: translation, teaching strategies, agency, theory, challenge.

\section{Introduction}

Translation teaching has begun in the 20th century. The practice of teaching translation was often done by discussing translation theories and translating texts with the students in the classroom. However, beside of training their translation skills, students also need to have a real-life experience as professional translators. By this way, students will have more experiences in translating different kinds of text, and also will get used to solve the challenges that translators faced in running a translation agency. 
Therefore, one strategy to develop students' translation skills is by giving students a project to build their own translation agency. This study aims to see the challenges that students faced in conducting their translation agency, the problem solving that they made, and the advantages that they got after completing the project.

\section{Literature Review}

\section{Translation Teaching Strategies}

Many translators did not receive formal training in translating text. They learned to translate text from their personal experiences. This study is exploring how translation field could be taught. This article reports the observations and personal experiences the students have in running their own translation agency outside of the classroom. Students' adventure in the world of translators will be beneficial for them to learn more about entrepreneurship in translation world.

According to Nord (2009), translation teaching should be similar to the real practice of translation. Nord proposes the "functionalist didactics" that includes criteria to select texts to be translated in the classroom, how to classify the translation problems and procedures, how to monitor students' progress, and how to evaluate translations. However, Gile (2009) states that translation teaching should be centered on the translation process, instead of on the analysis of translation error. Gile also proposes class discussions about basic translatological concepts as: communication, quality, fidelity to the message understanding, and knowledge acquisition by using sources of information. Gile also adds that students should gather concepts and basic models while receiving feedback from their lecturers.

Then, Kiraly (2000) mentions that "translation is not a process to repeat or transfer". Kiraly thinks translation teaching as "collaborative learning, social constructivism, empowerment and reflexive practice to teach translation. Kiraly also agrees that collaborative learning environment is a place where students learn, guided by their professors who facilitate the individual construction of knowledge to solve the complex and real problems which can develop the cognitive flexibility and selfconcept in solving the translation problems.

Finally, it is also important to mention Hurtado (2005: 130) who writes that there are three basic elements in any translation teaching process: 1) Translation as what is going to be taught; 2) Translator's competence as knowledge and abilities required to translate; and, 3) The acquisition of the translator's competence as the mean to develop this competence.

Then, in their article, Bibiana Clavijo and Patricia Marin (2013: 72) explain that a study developed in a Columbian university was conducted to identify translation teaching strategies in Modern Language students who will work for organizations as language experts. The survey was taken from 57 students of the Business Translation II Course as a part of the curriculum of the modern Language Program at a university in Bogota, Columbia. The survey's topics are; resources, activities, categories, and modalities of the course. 
Then, it was found that $87.7 \%$ of the students selected online dictionaries and glossaries as their most important research tool rather than choosing other translation resources such as; printed dictionaries and company sites. After that, for the translation activities, translation project management is the closest activities to the real translation practice, and one of the less used in class. For the additional to the practice of translation, it was found that the teacher and preparation of a terminology database are the two most widely used methods because the teacher is still the center of knowledge in the classroom, which is closer to the traditional approach than socioconstructivist method.

Then, about the classroom interaction in the translation practice shows that individual translation is the most used in the class than group translations. For the assessment in the classroom, the professors corrected the whole group and gave a correct version. After analyzing the results obtained in their survey, Bibiana Clavijo and Patricia Marin (2013: 74) conclude that the professor use different resources and activities to develop the translator's competence in their students and also try to make them feel in a real professional context.

\section{Research Method}

The method of this research is descriptive qualitative method for translation (Toury, 1995) based on theoretical research compared to a survey applied to students of English Education Department who have learned about translation theories. The survey was taken from 28 students of the Translation I Course as a part of the curriculum of the English Education Department Program at the State Islamic University of North Sumatra. The survey was analyzed to see the the challenges that students faced in conducting their translation agency, the problem solving that they made, and the advantages that they got after completing the project.

\section{Discussion}

\section{The biggest challenge in conducting translation agency}

After analyzing the data, it can be seen that the biggest challenge the students faced in conducting their translation agency is advertising the translation agency (43\%), meeting a client $(36 \%)$, and translating the project $(21 \%)$. The students mention that they need to be more creative and innovative in advertising their translation agency. The students learn the methods of advertising by themselves and use different techniques to publish their translation agency. The students make video advertisements, brochures, and use their relations to talk about their translation agency. It can be seen on the following picture.

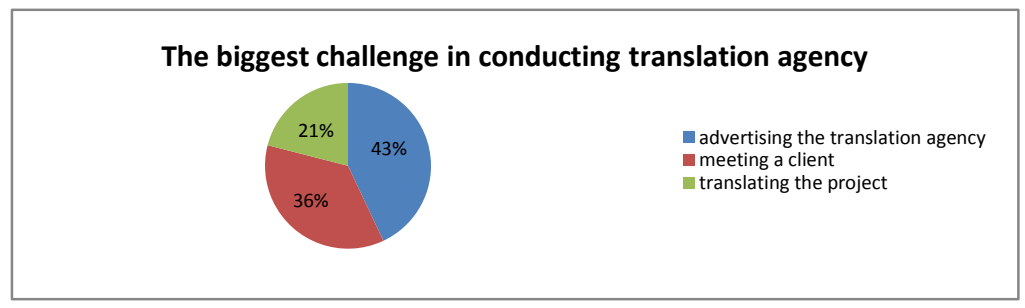

Chart 1. The biggest challenge in conducting translation agency 


\section{The challenges in promoting translation agency}

Following are some challenges that students faced in promoting translation agency including the problem solving:

a. The students have difficulty to convince the clients in using their translation agency service. The students mention that they needed to learn the skills of making good advertisements to promote the translation service. To do this, the students tried to find more information about techniques to persuade clients by reading a lot from books and the Internet.

b. The students have difficulty in using computer to create the advertisement video for their translation agency. The students should learn the way to add subtitles to the advertisement video. Then, the students consulted to their friends who can edit and add subtitles to the video. For the brochures, the students consulted to their friends who understand to use image editing software.

c. The students have difficulty to write clear and interesting information in the video and brochures in order to invite many clients. To cope with this challenge, the students did more research on the Internet to find unique and creative samples of advertisement videos and brochures.

d. The students have difficulty in determining the appropriate price for their translation service. For this, the students compared the price of translation service on the Internet. Some of the students also offered free delivery cost of the translation product to invite more clients.

e. The students have difficulty in using English for the advertisement video. The students are aware of their English proficiency; the correct intonation, word choice, and grammar to convince the clients in using their service. To prevent of making mistakes in the advertisement video, the students asked the proof-reader to check the sentences that they wanted to say in the advertisement video and the brochure.

f. The students have difficulty in giving appropriate responses to the comments given by the clients quickly and appropriately. To do this, the students try to communicate politely and give responses quickly to every question asked by the clients.

g. The students have difficulty to share the share the brochures in the place where they can get many clients. Then, the students promote their translation agency service to the social media on the Internet, and ask their friends to share the information as many as possible. Then, to share the hard-copy brochure, the students decided to share the brochures in many universities around Medan City.

h. The students have difficulty to build up their confidence in promoting their translation service in the advertisement video. To have confidence in persuading the clients in the video, the students practice a lot and rehearse many times before taking the video.

i. The students have difficulty to cooperate well with their friends. To maintain a good cooperation with the other members, the students try to communicate well as a group and discuss and solve any problem that they faced together. 


\section{The challenges in handling the clients of translation agency}

Following are the challenges that students faced in handling the clients of their translation agency:

a. The students do not have client for more than a week after promoting their translation services. After promoting their translation services, the students found that they do not get any client for more than a week. The students felt discouraged and thought that they would have no client who wanted to use their translation services. To solve this problem, the students tried to find their first clients from their close friends and relations. The students also improved the quality of their advertisements, either the video or the brochure. They promoted their translation service to their friends from other universities, social media's groups, and other departments in their university.

b. The students have difficulty to convince the clients about the product of their translation service. The students mentioned that they met different characters of clients. Some of the clients are easy to understand the service system of their translation agency, but some of the clients are difficult to handle as they do not believe with the quality of the translation product that the students' translation agency have. To solve this difficulty, the students try to convince the clients by asking the clients to compare the quality of their translation product to the quality of other machine translation on the Internet.

c. The students have difficulty in dealing with the clients that they have just met for the first time. They feel nervous to talk with the clients about the translation service that they have. As the clients are different in ages, genders, and cultures, the students are hard to communicate with some clients to convince them in using their translation service. Therefore, the students tried to practice communicating with their friends before meeting the real clients. The students also tried to build their confidence to talk with the clients by having their friends accompanying them together.

d. The students have difficulty in making an appointment with the clients who are far away and have tight schedules and do not have time to meet and communicate face to face. To solve this problem, the students talked to the clients via mobile phone either by texting the clients or talking through a video-call. The students also asked the clients to send the source text via e-mail, and sent the soft-copy of the translation product via e-mail.

e. The students have difficulty in bargaining the price of their translation service with the clients. Some students found that their clients were from their close friends or the people that they have known well, or they respect. Most of the clients asked the students for cheaper price for translating their text, yet they will not consider for a bad quality of translation. The students managed this problem by persuading the clients not to ask for the cheaper price as they can guarantee for the better translation product. The students also added their translation bonus service by giving free cost of delivering the translation product to the client's house. However, for the client's house that is far enough to reach, the students invited their friends to accompany them in finding and giving the translation product in the client's house. 
f. The students have difficulty in dealing with the clients who do not have e-mail. The students wrote in the survey that there were some clients who do not have e-mail to send the source text, yet sometimes the client's house was far enough. Therefore, the students asked to meet the clients directly to take the translation project in soft or hard-copied file.

g. The students have difficulty in managing their time to meet the deadline asked by the clients. When the students have many clients and translation projects to handle, the students confuse to meet the deadline from the clients. To solve this problem, sometimes, the students rejected several translation projects because they felt uneasy to manage their time to translate and to study at campus. Then, sometimes the students should cancel their weekend planning to translate the project.

\section{The challenges in translating the texts}

Following are the challenges that students faced in translating the texts:

a. The students have lack of vocabularies to translate the source text. To solve this problem, some students check the translation of some words from the Machine Translation on the Internet.

b. The students have difficulty in applying the translation procedures that they have learned in translation theory. To cope with this problem, the students learned again about the translation procedures from their books, the grammatical structure of English language, and consulted to their dictionaries.

c. The students have difficulty in translating texts with specific terminologies (specific words, unfamiliar words, idioms, slang words, and cultural words).

d. The students have difficulty in translating poetry and abbreviation. To solve this problem, the students checked the right abbreviation and expressions from the Internet.

e. The students have difficulty to translate disorganized source text. The source text that the students received was not written in a good structure. The language used inside sometimes had no subject or verb, yet in English a good sentence should have at least a subject and a verb. Then, the students found that there were also many typos in the source text. To solve this problem, the students contacted the owner of the source text and try to clarify the source text again.

f. The students have difficulty to meet the deadline of the project. After spreading their advertisements, the students had many projects to translate different kind of texts. Some of the clients asked the students to translate books, journal articles, and etc, and the deadline of the project was almost at the same time. To solve with the overload projects, the students invited more friends to join their translation agency. The other students decided to reject some projects from their clients and brought the client to other translation agencies.

\section{The advantages of translation agency project}

After conducting the Translation Agency Project, students realized many positive things. Following are the advantages of translation agency project mentioned by the students: 
a. The Translation Agency Project has improved their confidence and given positive feelings for them personally. The students expressed that solving the challenges that they faced in advertising their translation agency, meeting their clients, and translating the projects has improved students' confidence. The students feel less nervous and believe in their capability more than before conducting the translation agency project. The challenges that they encountered has trained them not to give up easily but try to find the problem-solving for the problems.

b. The Translation Agency Project has improved their English proficiency. In translating the texts from their clients, students should consult to dictionaries and find the equivalence for specific term from the Internet and books related to the source text. The students also learned and reviewed the use of correct English grammatical structure, punctuation, and word choices. In the end of translation agency project, the students have acquired many new words and expressions.

c. The Translation Agency Project has allowed the students to practice the translation theories that they have learned in the classroom. The students have learned about translation theories in the classroom. They discussed about translation procedures in translating text and some theories to produce the target text in their translation class. However, discussing the theories in the class was not enough for students to understand and practice the translation theory. Then, after they built their own translation agency, the students got real-life experiences as translators and solved the challenged that they faced alone and together as a team. Students feel that learning translation theory through direct practices is better than only learning the theory from their translation books.

d. The Translation Agency Project has given profit and let the students to develop new job opportunities for other people. Students learned to earn their own money from translation agency project. Because there are many projects from the clients, the students were difficult to handle the projects by themselves. Then, they asked other students to help them in translating the projects, and they shared the profit as a team. From this project, the students have widened their mindset that creating new jobs is better than finding jobs.

e. The Translation Agency Project has taught them new skills. In this project, the students did not only train their translation skills, but also encouraged them to learn new skills, such as; how to promote their translation agency better by using the computers and social networking systems (SNS), how to deal with the clients, and how to translate the text better. The students also learned about cooperation, collaboration, and built up their confidence and leadership skills.

\section{Conclusions}

Even though students of English Education Department students of the State Islamic University of North Sumatra often discuss translation theories and translate text in the classroom, they also need to learn and have a real-life experience as professional translators that will be useful for the students in the future. Translation Agency Project will be useful as an innovative strategy to teach translation subject. By developing their own translation agency, the students are able to face the challenges that translators often face. After analyzing the students' comments on the survey, it can be seen that the biggest challenge that students face in conducting their 
translation agency is advertising or promoting the translation agency $(43 \%)$, meeting or handling the client (36\%), and translating the texts $(21 \%)$. In promoting their translation service, the common problem that students have encountered is about computer skills. The students solved the problem by consulting to their friends and learned more from the Internet. In handling the clients, the students found that convincing the clients to use their translation services is the most challenging. To cope with this problem, the students learned additional skills; communication skills and computer skills, and did several rehearsals before meeting with the clients. Then, in translating the text, the students have difficulty in deciding the appropriate translation procedures to translate the texts. They also have difficulty to choose the most equivalent words. In the end, the students tried to read and discuss about translation procedures that they have learned before. After identifying the students' comments on the survey about the benefit of translation agency project, it can be concluded that Translation Agency Project is an effective and recommended strategy to teach translation theories in translation class because it will not only give students the real experience as entrepreneurs in translation field, but it will also build up students' confidence to have direct-practice of translation theories.

\section{References}

Clavijo, B., Martin, P. (2013). Identifying Translation Teaching Strategies: An Exploratory Study. International Journal of Humanities and Social Science: The Special Issue on Social Science Research (pp. 71-78). USA. Taken from: www.ijhssnet.com.

Gile, D. (2009). Basic Concepts and Models for Interpreter and Translator Training. Amsterdam: John Benjamins.

Hurtado, A. (2008) "Compétence en traduction et formation par compétences" in TTR: traduction, terminologie, rédaction, vol. $21, \mathrm{n}^{\circ} 1,2008, \mathrm{p} .17-64$ taken from: http://id.erudit.org/iderudit/029686ar.

Kiraly, D. (1995). Pathways to Translation.Pedagogy and Process. Kent (O), Londres: The Kent State University Press.

Kiraly, D. (2000). A Social Constructivist Approach to Translator Education Empowerment from Theory to Practice. Manchester. St. Jerome Publishing.

Kiraly, D. (2003). From Instruction to Collaborative Construction: A passing fad or the promise of a paradigm shift in translator education? en Baer B. y Koby G. (eds.) Beyond the Ivory Tower. Rethinking translation pedagogy. American Translators Association Scholarly Monograph Series, Vol. XII. Amsterdam, Filadelfia: John Benjamins. 3-27.

Mustafa, F. (2015). Using corpora to design a reliable test instrument for English proficiency assessment. Proceedings of the TEFLIN International Conference: Teaching and assessing L2 learners in the 21st century (pp. 344-354). Denpasar: Universitas Udayana.

Newmark, P. (2001). A Textbook of Translation. Edinburgh. Pearson Education Limited. Nord, Ch. (2009). El funcionalismo en la enseñanza de traducción at Revista latinoamericana de traducción 